Research Article

\title{
Behaviour of Eccentric Concrete Columns Reinforced with Carbon Fibre-Reinforced Polymer Bars
}

\author{
Zrar Sedeeq Othman $\mathbb{D}^{1}$ and Ahmed Heidayet Mohammad ${ }^{2}$ \\ ${ }^{1}$ Ph. D. Student, Civil Engineering Department, Salahaddin University-Erbil, Erbil, Iraq \\ ${ }^{2}$ Assistant Professor, Civil Engineering Department, Salahaddin University-Erbil, Erbil, Iraq \\ Correspondence should be addressed to Zrar Sedeeq Othman; zrar.othman@su.edu.krd
}

Received 30 April 2019; Accepted 7 July 2019; Published 22 July 2019

Academic Editor: Giulio Dondi

Copyright ( 2019 Zrar Sedeeq Othman and Ahmed Heidayet Mohammad. This is an open access article distributed under the Creative Commons Attribution License, which permits unrestricted use, distribution, and reproduction in any medium, provided the original work is properly cited.

\begin{abstract}
The use of steel bars as reinforcement is not preferred in some concrete structures because steel causes corrosion or electric magnetic field problems. One of the best alternatives to steel bars is carbon fibre-reinforced polymer (CFRP) bars. The experimental program consisted of 18 reinforced rectangular concrete columns under different eccentric loadings. Out of the 18 columns, 15 were reinforced with CFRP longitudinal rebars and ties and 3 were reinforced with conventional steel rebars and ties as reference columns. The following parameters were included in this study: the replacement of steel with CFRP bars, eccentricity of load, longitudinal reinforcement ratios, and tie spacing. Test results in terms of load-strain, load-mid height deflection curves, and crack patterns showed that the column reinforced with CFRP bars behaved similarly to the concrete column reinforced with conventional steel bars with a slight difference in axial and flexural capacity. The increment in CFRP longitudinal reinforcement ratios from $1.4 \%$ to $2.0 \%$ and $3.6 \%$ reasonably increased the maximum carrying capacity for different eccentricities used herein. The axial ratios of experimental to theoretical results $\left(P_{\text {Exp. }} / P_{\text {Theor. }}\right)$ were determined for specimens in the present work and those from previous studies to assess the efficiency of the theoretical models.
\end{abstract}

\section{Introduction}

Columns are the main elements of reinforced concrete (RC) structures and carry loads from the upper to the lower floors until they are released to the footing. Column failure can cause disaster in a building. Corrosion in reinforcing steel is a problem in conventional RC, especially in harsh climatic zones, coastal areas, or regions that contain corrosion factors. In some special buildings, such as magnetic resonance image (MRI) rooms and other radiation facilities, the presence of steel around MRI apparatus must be avoided. Fibre-reinforced polymer (FRP) is a good alternative for this condition because of its noncorrosive, nonmagnetic, and nonconductive materials. Thus, problems of corrosion and electromagnetic interference can be averted using FRP.

There are three main types of FRP, namely, aramid, glass, and carbon fibres, which are embedded in polymer. Experimental data on the role of carbon FRP (CFRP) as longitudinal bars in compression members are limited. Due to the lack of data, the current American Concrete Institute (ACI) 440.1R-15 [1] design guidelines do not recommend the use of FRP bars for resisting compressive stress.

Few experimental studies have been conducted to investigate the behaviour of the concrete column reinforced with GFRP under concentric loading [2-9]. It was concluded that columns reinforced with GFRP bars behave in the same manner as those reinforced with steel bars. GFRP's contribution to the maximum capacity of the column ranges from $5 \%$ to $10 \%$, so they can be used in compression members. GFRP ties in the square column and the GFRP spiral in the circular column affect the strength and ductility of the column, and their spacing remarkably influences the mode of failure.

Experimental investigations on the concrete column reinforced with CFRP subjected to concentric loading are rare. Afifi et al. [10] tested 11 full-scale circular concrete columns reinforced with CFRP bars and spirals and found that CFRP and steel RC columns behave similarly up to their 
peak loads. CFRP bars are effective in resisting compression and contributes $12 \%$ column capacity on average. Mohamed et al. [11] tested 14 full-scale circular columns reinforced with longitudinal FRP (GFRP or CFRP) bars and confined with circular FRP spirals or hoops. The GFRP and CFRP RC columns behave similarly to columns reinforced with steel. Using GFRP and CFRP spirals or hoops yields sufficient restraint against the buckling of the longitudinal FRP bars and provide good confinement of concrete core in postpeak stages. Tobbi et al. [12] investigated square concrete columns reinforced longitudinally with FRP (e.g., GFRP or CFRP) or steel bars using FRP as transverse reinforcement. They reported that FRP bars contribute in resisting compressive stress as longitudinal reinforcement for concrete columns subjected to concentric compression. This feature must not be neglected. CFRP transverse reinforcement with large spacing and low volumetric ratio performs better than GFRP at the same spacing and volumetric ratio.

There were a limited number of studies carried out on the behaviour of FRP RC columns under eccentric loads, and rarely they were columns reinforced with CFRP bars. Choo et al. [13] and Deiveegan and Kumaran [14] reported that columns with low reinforcement ratio of the GFRP RC column exhibit brittle tension failure, and the increase in this percentage leads to the same behaviour as the column with conventional steel. Columns with GFRP reinforcement show no yielding of reinforcement as that found in steel because of the linear elastic behaviour of GFRP bars. Choo et al. [15] presented an approach to calculate the minimum longitudinal reinforcement ratio of FRP bars, which is required to avert brittle tension failure. Issa et al. [16] investigated the behaviour of the GFRP RC column under eccentrically axial loads. They stated that steel-reinforced columns deform at a lesser extent than GFRP-reinforced column, and tie spacing minimally affects maximum lateral deflection and ductility. This finding is in contrast with our concept of using ties in reinforced columns. Zadeh and Nanni [17] developed a methodology for the design of the concrete column reinforced with GFRP bars and ties. The method is applicable only to buildings of limited size and height. The ultimate design strain for the GFRP bar is recommended to not exceed $1 \%$ to avoid overstated deflections. The contribution of the cross-sectional area of the GFRP bar in compression can be replaced by the equivalent area of concrete. Hadi et al. [18] investigated the use of GFRP bars and GFRP helices in RC columns. They concluded that the axial load and bending moment capacity of the GFRP RC columns are smaller than those of conventional steel RC columns. However, the ductility of GFRP RC columns is very close to the that of steel $\mathrm{RC}$ columns. Thus, ignoring the contribution of GFRP bars in compression results in considerable difference between the analytical and experimental results. Hadhood et al. $[19,20]$ experimentally investigated circular high-strength and normal strength concrete columns reinforced with CFRP as longitudinal bars and spirals. They indicated that with providing minimum reinforcement ratio equal to $1 \%$, the failure of eccentric columns will be concrete crushing at compression side followed by crushing of compression bars. The test results showed that the columns reinforced with the
CFRP bar have less axial capacity than those reinforced with the steel bar at low, moderate, and high eccentricity, whereas at extreme eccentricity, CFRP concrete columns showed higher capacity. Guérin et al. [21] tested full-scale rectangular concrete columns reinforced with GFRP bars. The behaviour of the GFRP bar RC column was comparable to its steel RC column counterpart at the same eccentricity. The specimens show compression failure for a small eccentricity of up to $0.2 \mathrm{~h}$. However, compression-ductile failure is the prevailing failure mode at $0.4 \mathrm{~h}$ eccentricity, and tensioncontrolled failure occurs in GFRP RC columns at high eccentricity $(0.8 \mathrm{~h})$. Raza et al. [22] stated that the behaviour of concrete columns reinforced with GFRP bars can be simulated by nonlinear finite element analysis using ABAQUS Standard. The numerical results exhibited good agreement with the experimental results. Elmessalami et al. [23] reviewed previous literatures on the behaviour of FRP RC compression members. They gathered data and assessed equations proposed by many researchers for predicting the load-carrying capacity of columns. The analysis shows that CFRP bars have same or more contribution in load capacity of the column than steel bars, whereas GFRP bars have less.

Most of the previous studies have examined circular concrete columns reinforced with GFRP bars, which exhibit a low modulus of elasticity, whereas CFRP bars have a higher modulus of elasticity close to steel. Therefore, GFRP and CFRP show different behaviours under loads that influence the strength and ductility of the concrete column. Furthermore, studies on concrete columns reinforced with CFRP bars are rare. Therefore, experimental investigations were needed to study the behaviour of concrete columns reinforced with CFRP bars. This research involves investigating the behaviour of square concrete columns reinforced with CFRP bars and subjected to eccentric load. A proposed approach with other existing analytical methods will be assessed with test results of rectangular and circular concrete columns reinforced with FRP rebars from present work and previous literatures.

\section{Experimental Program}

The test program consisted of 18 concrete columns measuring $150 \mathrm{~mm} \times 150 \mathrm{~mm}$ in cross section, $1500 \mathrm{~mm}$ in overall height, and $900 \mathrm{~mm}$ in midheight test. The column could be specified as a short column because the slenderness ratio $\left(\mathrm{kl}_{\mathrm{u}} /\right.$ $r$ ) of the specimens was equal to 20 , that is, less than 22 based on ACI 318-14 [24]. All of the columns have enlarged heads at both ends to apply eccentric loading. The enlargements were designed as a bracket to allow column failures to occur within the test height instead of column ends.

The tested specimens were divided into six groups, as shown in Table 1. Each group consisted of three concrete columns with the same reinforcement details but tested under different eccentricity conditions of 0,75 , and $150 \mathrm{~mm}$ ( $e / h$ equal to $0.0,0.5$, and 1.0 , respectively). The specimens were identified on the basis of the longitudinal and tie reinforcement material (steel or CFRP), diameter of the longitudinal bar, tie spacing, and eccentricity amount of the applied load. For example, specimen C12-T90-E0.0 is 
TABle 1: Details of tested specimens.

\begin{tabular}{|c|c|c|c|c|c|c|c|}
\hline G. & No. & Specimen & $e / h$ & $\rho(\%)$ & Type of reinforcement & Longitudinal reinforcement & Transversal reinforcement \\
\hline \multirow{3}{*}{1} & 1 & S12-T90-E0.0 & 0.0 & \multirow{3}{*}{2.0} & \multirow{3}{*}{ Steel } & \multirow{3}{*}{$4 \emptyset 12 \mathrm{~mm}$} & \multirow{3}{*}{ Ø6@90mm } \\
\hline & 2 & S12-T90-E0.5 & 0.5 & & & & \\
\hline & 3 & S12-T90-E1.0 & 1.0 & & & & \\
\hline \multirow{3}{*}{2} & 4 & C10-T90-E0.0 & 0.0 & \multirow{3}{*}{1.4} & \multirow{3}{*}{ CFRP } & \multirow{3}{*}{$4 \varnothing 10 \mathrm{~mm}$} & \multirow{3}{*}{ Ø6@90 mm } \\
\hline & 5 & C10-T90-E0.5 & 0.5 & & & & \\
\hline & 6 & C10-T90-E1.0 & 1.0 & & & & \\
\hline \multirow{3}{*}{3} & 7 & C12-T90-E0.0 & 0.0 & \multirow{3}{*}{2.0} & \multirow{3}{*}{ CFRP } & \multirow{3}{*}{$4 \varnothing 12 \mathrm{~mm}$} & \multirow{3}{*}{ Ø6@90mm } \\
\hline & 8 & C12-T90-E0.5 & 0.5 & & & & \\
\hline & 9 & C12-T90-E1.0 & 1.0 & & & & \\
\hline \multirow{3}{*}{4} & 10 & C16-T90-E0.0 & 0.0 & \multirow{3}{*}{3.6} & \multirow{3}{*}{ CFRP } & \multirow{3}{*}{$4 \varnothing 16 \mathrm{~mm}$} & \multirow{3}{*}{ Ø6@90 mm } \\
\hline & 11 & C16-T90-E0.5 & 0.5 & & & & \\
\hline & 12 & C16-T90-E1.0 & 1.0 & & & & \\
\hline \multirow{3}{*}{5} & 13 & C12-T140-E0.0 & 0.0 & \multirow{3}{*}{2.0} & \multirow{3}{*}{ CFRP } & \multirow{3}{*}{$4 \varnothing 12 \mathrm{~mm}$} & \multirow{3}{*}{ Ø6@140mm } \\
\hline & 14 & C12-T140-E0.5 & 0.5 & & & & \\
\hline & 15 & C12-T140-E1.0 & 1.0 & & & & \\
\hline \multirow{3}{*}{6} & 16 & C12-T40-E0.0 & 0.0 & \multirow{3}{*}{2.0} & \multirow{3}{*}{ CFRP } & \multirow{3}{*}{$4 \varnothing 12 \mathrm{~mm}$} & \multirow{3}{*}{ Ø6@40mm } \\
\hline & 17 & C12-T40-E0.5 & 0.5 & & & & \\
\hline & 18 & C12-T40-E1.0 & 1.0 & & & & \\
\hline
\end{tabular}

reinforced with CFRP bars and ties, four $12 \mathrm{~mm}$ diameter bars were used as longitudinal reinforcement, tie spacing was $90 \mathrm{~mm}$, and it was tested under concentric load. The first group (S12-T90, reference specimens) consisted of three concrete columns reinforced with four $\varnothing 12$ longitudinal steel bars and $\varnothing 6$ steel ties placed at a spacing of $90 \mathrm{~mm}$. The columns in the five other groups were reinforced with CFRP bars and ties. The second group (C10-T90) consisted of three concrete columns reinforced with four $\varnothing 10$ longitudinal CFRP bars and Ø6 CFRP ties placed at a spacing of $90 \mathrm{~mm}$. The longitudinal reinforcement for the columns in groups three and four comprised four $\varnothing 12$ and four $\varnothing 16$ bars, respectively. The tie spacing was the same as that of the second group. In the fifth and sixth groups, the tie reinforcement consisted of 66 CFRP ties placed at spacing of 140 and $40 \mathrm{~mm}$ respectively, and the longitudinal reinforcement is as same as those of the columns in group three. Figure 1 shows the dimensions and details of the reinforcement of the tested specimens. All of the experimental works were carried out in the concrete and structural laboratory of the Civil Engineering Department, Salahaddin University-Erbil.

All of the specimens were casted simultaneously from the same ready-mix-concrete batch by using ordinary Portland cement. The average concrete compressive strength for the concrete based on the $100 \mathrm{~mm} \times 200 \mathrm{~mm}$ cylinder samples was $44.7 \mathrm{MPa}$ [25]. The longitudinal and tie reinforcements for group S12-T90 specimens were $\emptyset 12$ and $6 \mathrm{~mm}$ deformed steel bars with yield strengths of 537 and $533 \mathrm{MPa}$ and ultimate strengths of 624 and $592 \mathrm{MPa}$, respectively. CFRP bars with diameters of 10,12 , and $16 \mathrm{~mm}$ were used as longitudinal reinforcements and those of $6 \mathrm{~mm}$ diameter were used as tie reinforcements. According to the manufacturer's test sheet, the average ultimate tensile strength for all diameters was $2000 \mathrm{MPa}$, as shown in Table 2. The CFRP bars were provided by Chongqing Yangkai Import \& Export Trade Co., Ltd., Chongqing, China.
Plywood sheets were used to construct the formwork used for all concrete columns. The steel and CFRP reinforcements were assembled and fixed in the form. The manufacturer prepared CFRP ties with a $120 \mathrm{~mm} \times 120 \mathrm{~mm}$ outer dimension. The steel ties were prepared with the same dimension. The clear covers used to the face of the ties for all specimens was $15 \mathrm{~mm}$. Figure 2 shows a typical steel and CFRP reinforcement cage assembled for the specimens. The formwork moulds were placed horizontally on level ground. Concrete was placed into the formwork in two layers. Each layer of concrete was vibrated using an electric vibrator. The columns and control specimens were cast from the same batch and cured by covering with a damp burlap and plastic sheeting to maintain moisture conditions. The curing process was continued for 28 days.

The test specimens were loaded under a computerised compression testing machine with a maximum capacity of $2,500 \mathrm{kN}$. Loading was carried out by load control at a rate of $1.1 \mathrm{kN} / \mathrm{sec}$ until failure occurred. Figure 3 shows a typical test setup and loading conditions. Enlargement ends of each column were confined by CFRP sheets (with $100 \mathrm{~mm}$ height) to avoid bearing premature failure at the ends. An $8 \mathrm{~mm}$ thick rubber was used as capping on the top and bottom ends of each column specimen to ensure uniform loading distribution from the machine to the column surface. The column specimens were approached to a pin connected at both ends. Special care was taken to ensure that the column was vertically aligned. Eccentricity was provided by three grooves fared beside one another, that is, $75 \mathrm{~mm}$ from centre to centre. The electrical resistance strain gauge was mounted on the middle of two opposite longitudinal bars, that is, one in the compression and the other in the tension side, for the measurement of longitudinal bar strain. Another strain gauge was attached to the compression face of the column at midheight for the measurement of concrete compression strain. In addition, dial gauge was positioned at midheight to measure the lateral deflection of the column during the loading stage. 


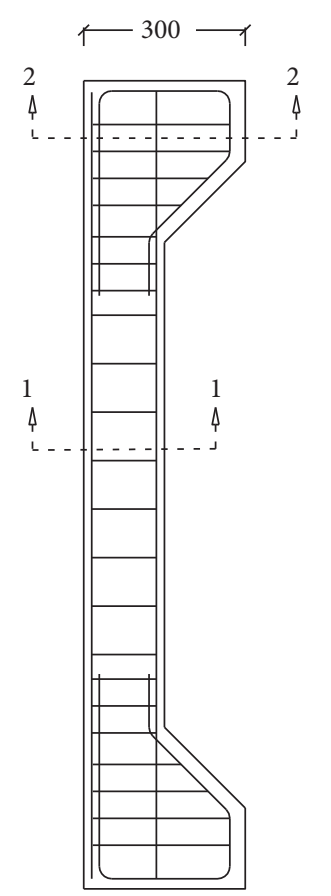

Longitudinal section of concrete columns reinforced with steel bar

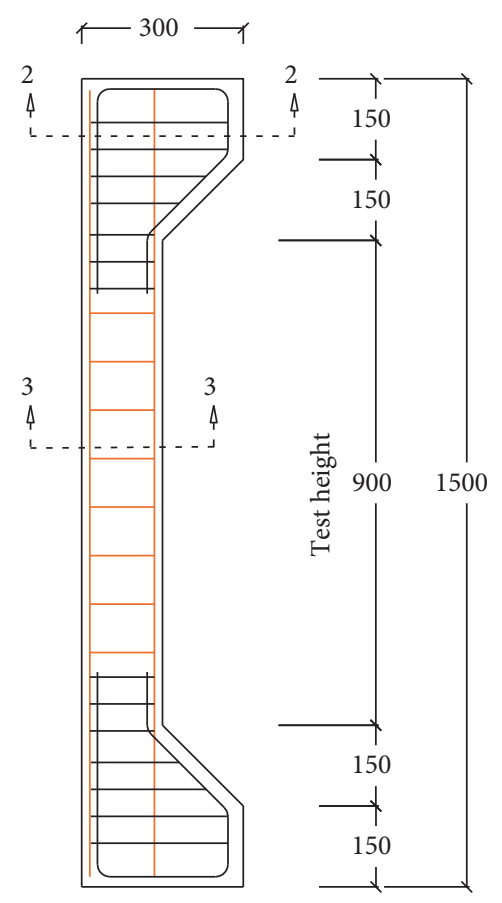

Longitudinal section of concrete columns reinforced with CFRP bar

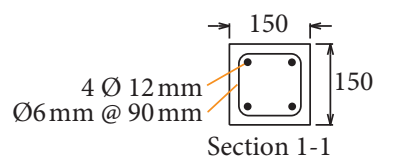

for group 1 (S12-T90)

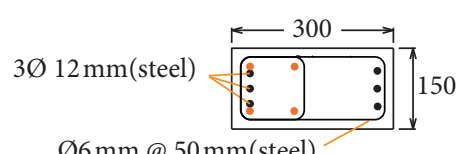

Ø6mm@50mm(steel)

Section 2-2

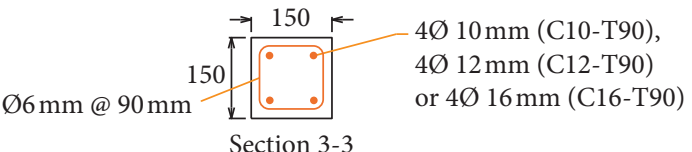

for groups 2,3 , and 4

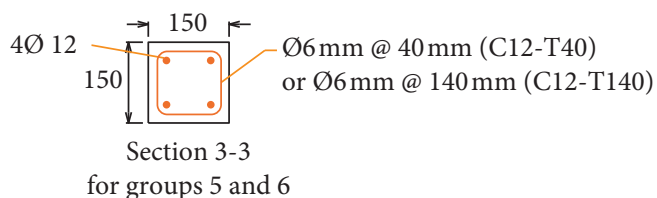

FIGURE 1: Details of reinforcement of the tested specimens (dimensions are in $\mathrm{mm}$ ).

TABLE 2: Mechanical properties of CFRP bars.

\begin{tabular}{lcccccc}
\hline Diameter $(\mathrm{mm})$ & Area $\left(\mathrm{mm}^{2}\right)$ & Density $\left(\mathrm{g} / \mathrm{cm}^{3}\right)$ & Weigh $(\mathrm{g} / \mathrm{m})$ & Tensile strength $(\mathrm{MPa})$ & $\begin{array}{c}\text { Ultimate tensile } \\
\text { strain }(\%)\end{array}$ & Modulus of elasticity $(\mathrm{GPa})$ \\
\hline 6 & 28 & 1.7 & 47.6 & 2000 & 1.35 & 148 \\
10 & 78.5 & 1.7 & 133.5 & 2000 & 1.33 & 150 \\
12 & 113 & 1.7 & 192.1 & 2000 & 1.38 & 145 \\
16 & 200 & 1.7 & 340 & 2000 & 1.32 & 151 \\
\hline
\end{tabular}

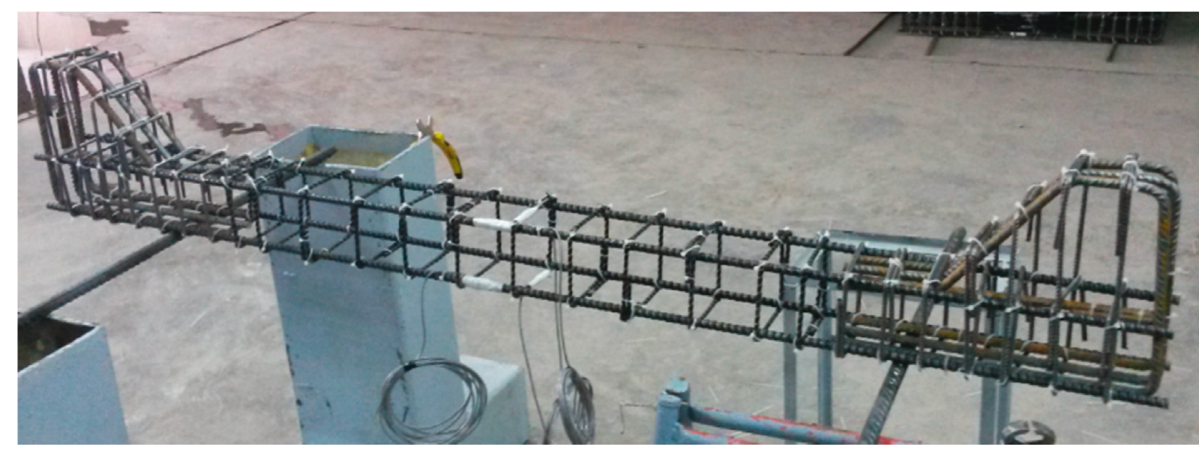

FIgURE 2: Typical reinforcement cage.

\section{Experimental Results and Discussion}

This section presents the test results of steel RC columns and CFRP RC columns. All specimens were tested until they failed and reached their maximum carrying capacity, and the machine recorded the data. Table 3 shows the maximum load, lateral displacement at maximum load, and maximum moment of all of the specimens. Maximum moment was calculated as the maximum load multiplied by the summation of initial eccentricity and lateral displacement at maximum load. In the following sections, the behaviour and failure modes, strain in longitudinal reinforcement, lateral deflection, and effect of the parameters on the maximum carrying capacity of the columns are discussed. 


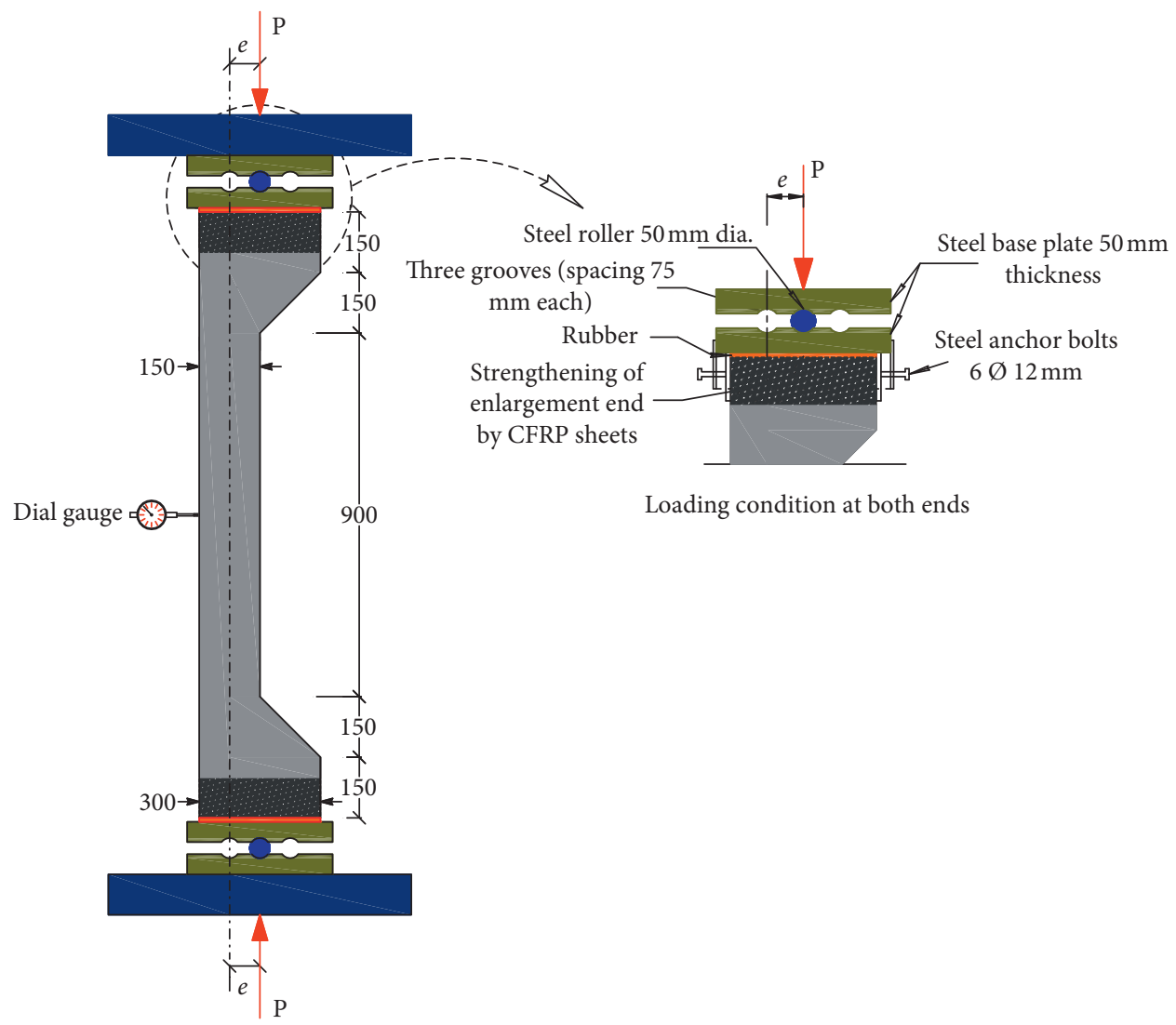

FIGURE 3: Loading condition at both ends of column specimens.

TABle 3: Experimental test results and effect of test parameters on the column axial capacity.

\% Change (increase or decrease) in column axial capacity

No. G. Specimen $\quad e / h \rho(\%) P_{\max }(\mathrm{kN}) \Delta_{\max }(\mathrm{mm}) \quad M_{\max }(\mathrm{kN} \cdot \mathrm{m})$

Relative to Due to

Due to eccentricity conventional Due to decrease steel bars increase in $\rho$ tie

\begin{tabular}{|c|c|c|c|c|c|c|c|c|c|c|c|}
\hline 1 & & S12-T90-E0.0 & 0.0 & & 916 & 1.55 & 1.42 & 0.0 & 0.0 & - & - \\
\hline 2 & 1 & S12-T90-E0.5 & 0.5 & 2.0 & 297 & 13.81 & 26.38 & -67.6 & 0.0 & - & - \\
\hline 3 & & S12-T90-E1.0 & 1.0 & & 130 & 19.00 & 21.97 & -85.8 & 0.0 & - & - \\
\hline 4 & & C10-T90-E0.0 & 0.0 & & 855 & 3.47 & 2.97 & 0.0 & - & 0.0 & - \\
\hline 5 & 2 & C10-T90-E0.5 & 0.5 & 1.4 & 258 & 17.96 & 23.98 & -69.8 & - & 0.0 & - \\
\hline 6 & & C10-T90-E1.0 & 1.0 & & 119 & 23.68 & 20.67 & -86.1 & - & 0.0 & - \\
\hline 7 & & C12-Т90-E0.0 & 0.0 & & 909 & 3.54 & 3.22 & 0.0 & -0.8 & 6.3 & 1.1 \\
\hline 8 & 3 & C12-Т90-E0.5 & 0.5 & 2.0 & 262 & 18.00 & 24.37 & -71.2 & -11.8 & 1.6 & -0.8 \\
\hline 9 & & C12-Т90-E1.0 & 1.0 & & 126 & 18.09 & 21.18 & -86.1 & -3.1 & 5.9 & -2.3 \\
\hline 10 & & C16-Т90-E0.0 & 0.0 & & 960 & 0.80 & 0.77 & 0.0 & - & 12.3 & - \\
\hline 11 & 4 & C16-T90-E0.5 & 0.5 & 3.6 & 290 & 18.34 & 27.11 & -69.8 & - & 12.6 & - \\
\hline 12 & & C16-T90-E1.0 & 1.0 & & 137 & 20.62 & 23.37 & -85.7 & - & 15.1 & - \\
\hline 13 & & $\begin{array}{c}\text { C12-T140- } \\
\text { E0.0 }\end{array}$ & 0.0 & & 899 & 1.30 & 1.17 & 0.0 & - & - & 0.0 \\
\hline 14 & 5 & $\begin{array}{l}\text { C12-T140- } \\
\text { E0.5 }\end{array}$ & 0.5 & 2.0 & 264 & 13.98 & 23.49 & -70.6 & - & - & 0.0 \\
\hline 15 & & $\begin{array}{l}\text { C12-T140- } \\
\text { E1.0 }\end{array}$ & 1.0 & & 129 & 19.17 & 21.82 & -85.7 & - & - & 0.0 \\
\hline 16 & & C12-T40-E0.0 & 0.0 & & 925 & 1.19 & 1.10 & 0.0 & - & - & 2.9 \\
\hline 17 & 6 & C12-T40-E0.5 & 0.5 & 2.0 & 237.7 & 17.23 & 21.92 & -74.3 & - & - & -10.0 \\
\hline 18 & & C12-T40-E1.0 & 1.0 & & 113 & 19.01 & 19.10 & -87.8 & - & - & -12.4 \\
\hline
\end{tabular}

The negative sign in front of the numbers represent the reduction in strength of the specimen relative to the column that is considered reference for the respective specimens. 
3.1. Behaviour and Failure Modes. In general, the column specimens under concentric loading displayed good appearance without evident cracks or deflection but suddenly failed with little or no advance warning. However, the columns subjected to eccentric loading $(0.5 \mathrm{~h}$ and $1.0 \mathrm{~h})$ failed when the concrete was crushed in the compression face of the column after a clear lateral displacement and appearance of cracks that propagated at tension face. These signs were remarkably more pronounced at a high $e / h$ of 1.0 than at 0.5 .

3.1.1. Concentric Loading Columns $(e=0)$. No cracks were observed in column S12-T90-E0.0 when load was increased up to the measured failure load. At the failure load, the concrete suddenly crushed explosively near the bottom end of the test height region. The failure unexpectedly occurred. The crushing of concrete was followed by the buckling of the longitudinal reinforcement bars, as shown in Figure 4.

Column specimens reinforced with CFRP bars and ties behaved similarly to the specimens reinforced with steel. Failure occurred in the test height by sudden and unexpected crushing of the concrete. While the longitudinal CFRP bars ruptured after crushing the concrete and the ties were opened or ruptured, except for column specimen C12-T40E0.0, which has less tie spacing $(40 \mathrm{~mm})$, the longitudinal bars were partially ruptured. This finding indicates that this spacing was more effective than the others and can be greatly beneficial for longitudinal CFRP under pure compression.

3.1.2. Columns with Medium Eccentric Loading ( $e=0.5 \mathrm{~h})$. The columns subjected to eccentricity loading starting from $e=0.5 h$ showed significantly different behaviours and strengths relative to concentric loading. After the columns with $e=0.5 h$ were loaded, the first crack occurred horizontally in the middle region of the column in the tension side when the load reached $15.5 \%-18.9 \%$ of the maximum load for columns reinforced with CFRP bars and $15.8 \%$ of the maximum load for the column reinforced with conventional steel. With increasing the load, cracks appeared parallel to this first crack along the tension side of the column. As the load on the column increased, these cracks were extended, and the neutral axis moved opposite to the face of the first crack (i.e., the depth of the compression stress area was decreased). The midheight cracks were longer and wider than the rest, as shown in Figure 5. Towards the enlarged ends area, the parallel cracks became shorter, and their width became smaller compared with the midheight cracks. Vertical cracks immediately occurred at the compression side with close to the maximum load, resulting in the concrete crushing and column collapse.

3.1.3. Columns with High Eccentric Loading ( $e=1.0 h)$. After the specimens were loaded, the first cracking in the middle area of the column occurred at a lower load compared with the columns with $e=0.5 h$ due to high eccentricity applied. This high eccentricity led to the occurrence of moments that caused high tensile stress at the opposite side to the applied load position. The first cracks occurred at loads of $8 \%$ to $9 \%$ of the column strength. The distribution and propagation of the cracks that occurred after the first crack were similar to those of specimens with $e=0.5 h$, with difference in length and width due to the increase of eccentricity. An appreciable increase in lateral displacement was also observed. Column curvature during loading was clear even before failure occurred with high percentage. In the final stages before failure, $45^{\circ}$ cracks occurred in the column head at $70 \%-75 \%$ of the maximum load.

Figure 6 shows the failure mode and crack pattern of the specimens with $e=1.0 \mathrm{~h}$. For the columns reinforced with CFRP bars except C16-T90-E1.0 and C12-T40-E1.0, failure occurred almost near to the ends of test height of the column when the concrete was crushed in a limited concrete part compared with specimens with $e=0.5 \mathrm{~h}$. However, failure of the models C16-T90-E1.0 and C12-T40-E1.0 was observed where the crushing of the concrete occurred, which was somewhere near the midheight of the column. For the column reinforced with steel S12-T90-E1.0, the concrete was crushed exactly at the middle of test height of the column in a limited concrete part. The deformation of the longitudinal steel bar slightly exceeded the yield point. Thus, failure in this column could be described as tension failure, which led to the final crushing of compression concrete. In all of the specimens with high eccentric loading, cracking near the concrete crushing region was longer and wider than that of the rest.

For the CFRP-reinforced column specimens, after the failure occurred and the load was released, the cracks were closed, and the column returned to its straight structure after it was curved under the load. This phenomenon is an indication of the elastic behaviour of the CFRP bars until the failure point. The CFRP bars returned to their original length, and the column straightened again because the longitudinal bars did not reach failure point.

3.2. Strain in Longitudinal Bars. Strain in the longitudinal CFRP bar in the corresponding specimens reinforced with CFRP bars was higher than that in steel bars at the same load level. This finding was due to the lower modulus of elasticity of the CFRP bar compared with that of steel. The strain of the compression bars reached $-3590 \mu \varepsilon$ at a maximum load in the C12-T90-E0.0 model, which was equal to $26 \%$ of the ultimate tensile strain of the CFRP bar. This amount of strain was higher than that recorded for specimens C12-T90-E0.5 and C12-T90-E1.0 at their maximum load. For bars subjected to tension, the strain for specimen C12-T90-E1.0 was higher than that of C12-T90E0.5 and reached $3960 \mu \varepsilon$, which was equal to $28.7 \%$ of the ultimate tensile strain of the CFRP bars. Thus, the stress in the tension bar was approximately $574 \mathrm{MPa}$ and was very close to the yield stress of steel in the corresponding specimens reinforced with steel.

3.3. Lateral Deflection. The lateral deflection of the tested columns at midheight is an indication of column stiffness. In general, for all of the tested columns, the slope of loaddeflection curves was decreased, and deflection at maximum 

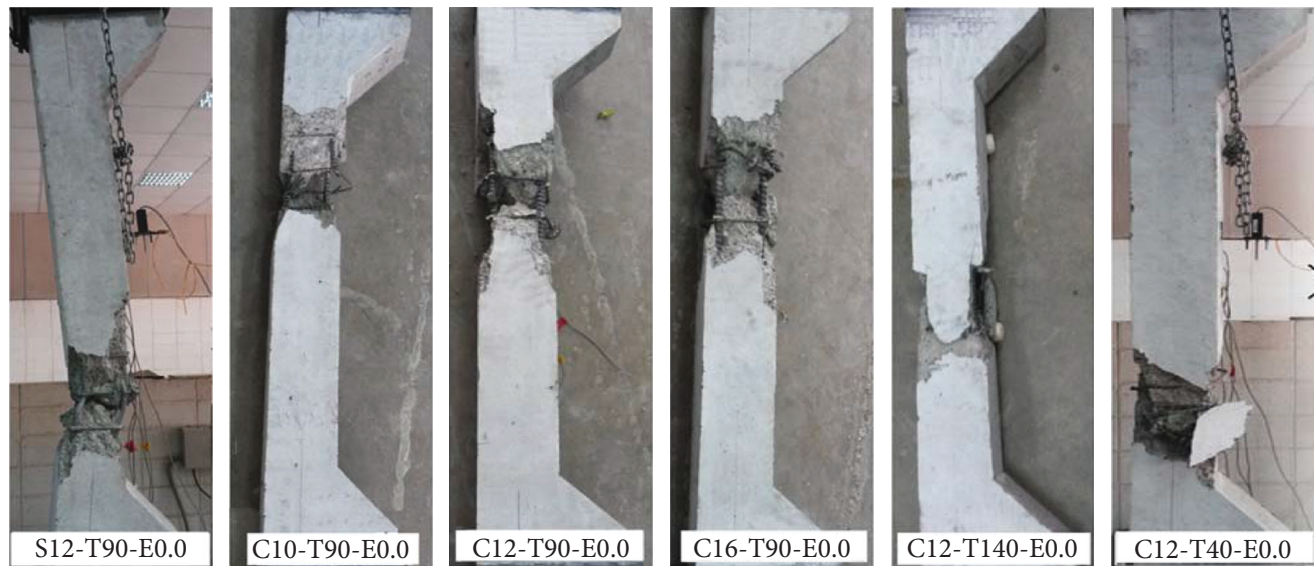

Figure 4: Crack pattern and mode of failure of concentric column specimens.
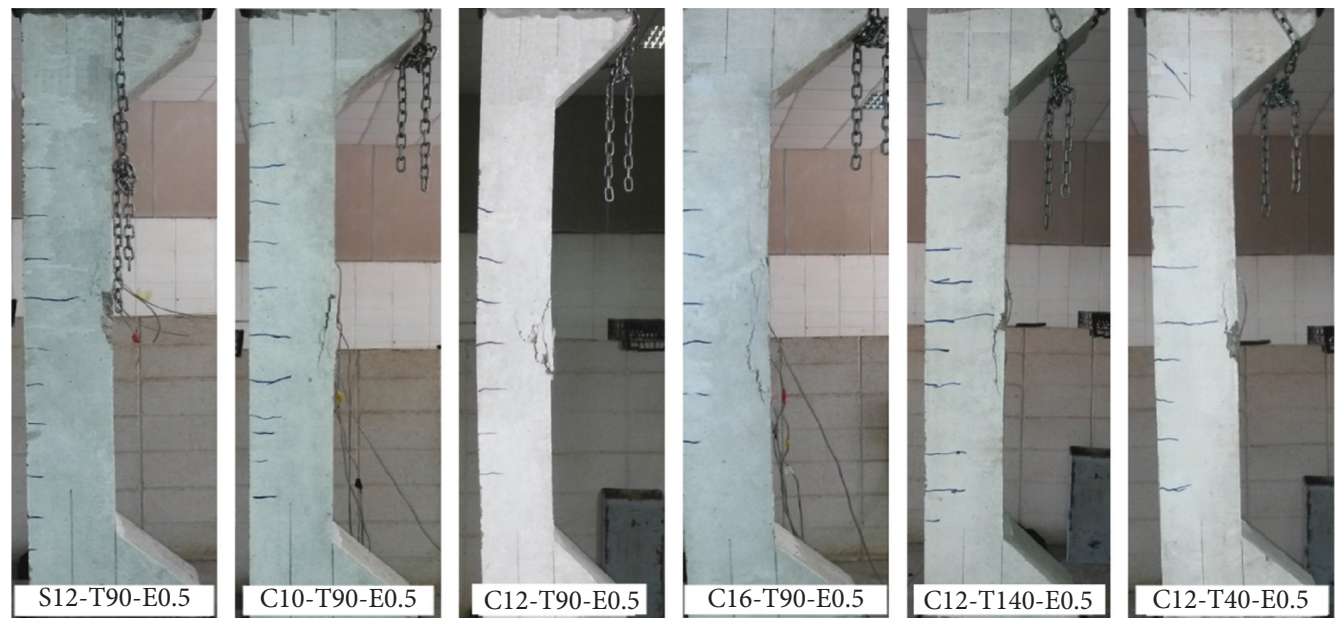

FIGURE 5: Crack pattern and mode of failure of column specimens with $e=0.5 \mathrm{~h}$.
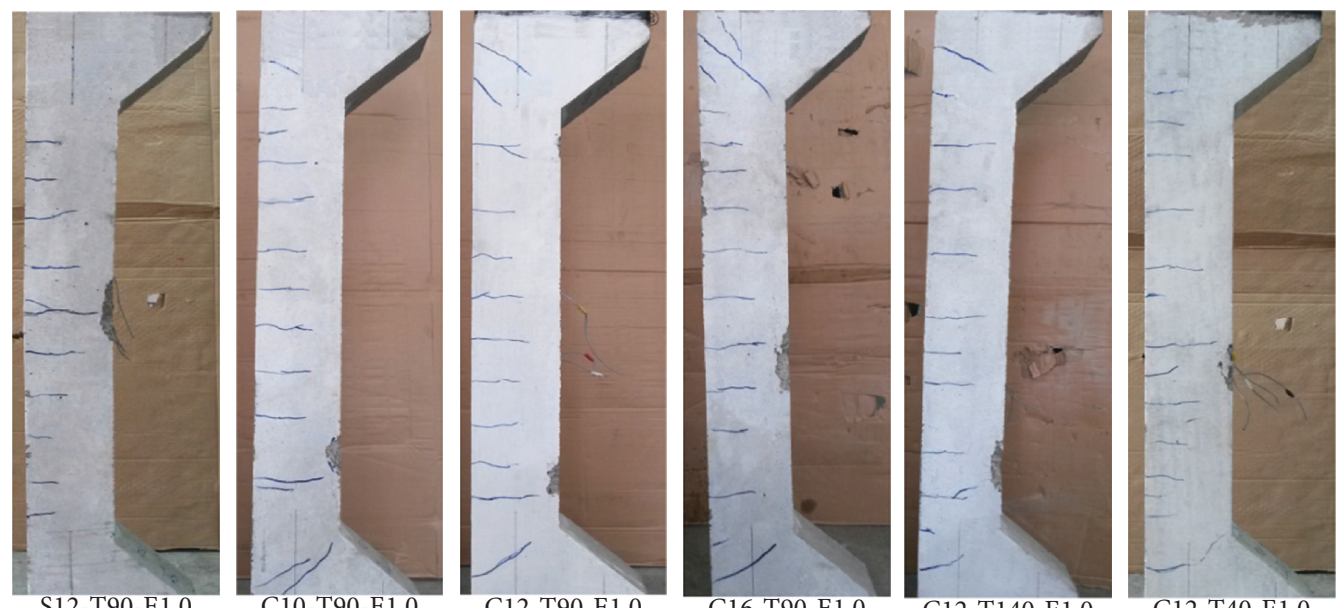

FIgURE 6: Crack pattern and mode of failure of column specimens with $e=1.0 \mathrm{~h}$.

load was increased as eccentricity was raised from 0.0 to $1.0 \mathrm{~h}$. Figure 7 shows that the slope of the load-deflection curves of CFRP-reinforced columns was lesser than that of the corresponding column specimens reinforced with steel.
Column reinforced with CFRP bars exhibited greater deflection at the maximum column capacity, except in cases of specimens subjected to high eccentricity $(e=1.0 h)$, in which deflections at the maximum load were close to each other. 


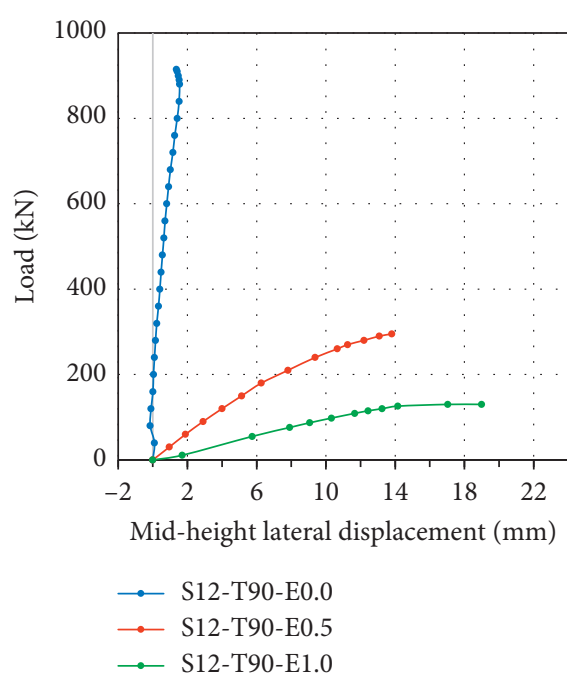

(a)

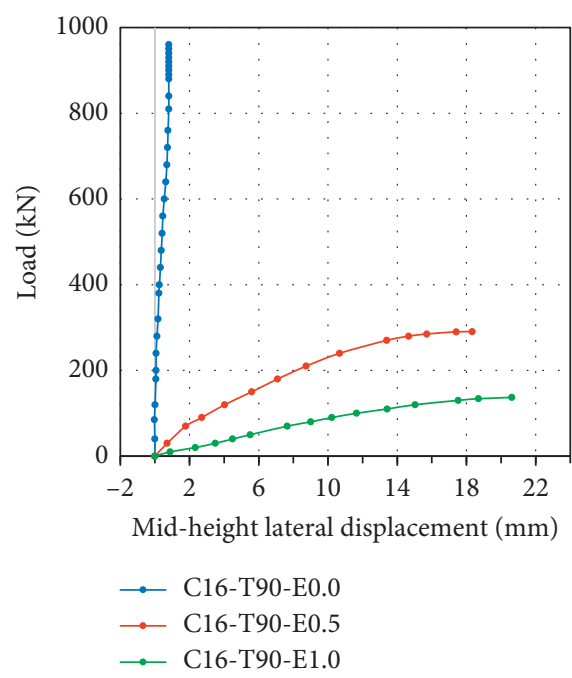

(d)

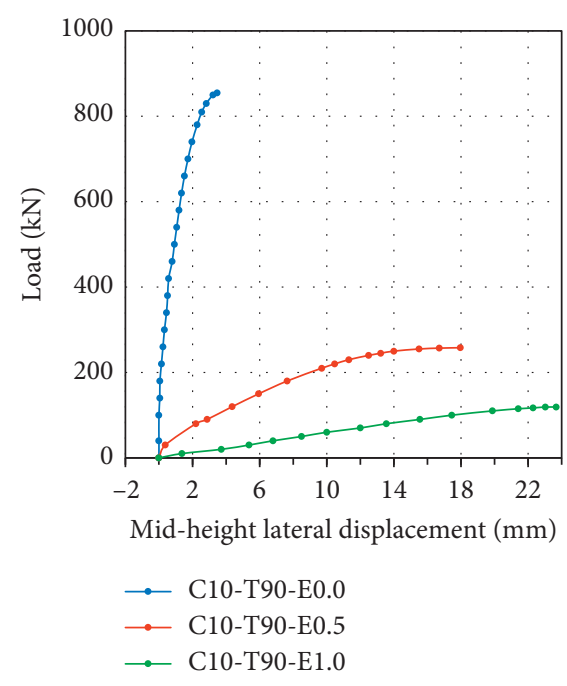

(b)

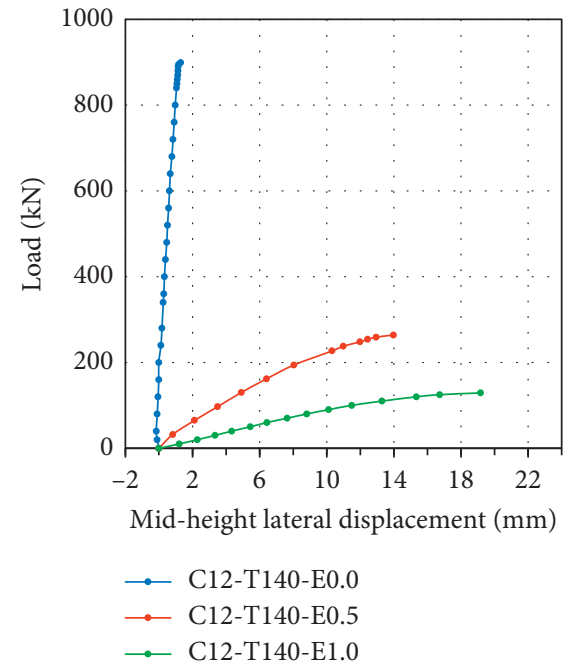

(e)

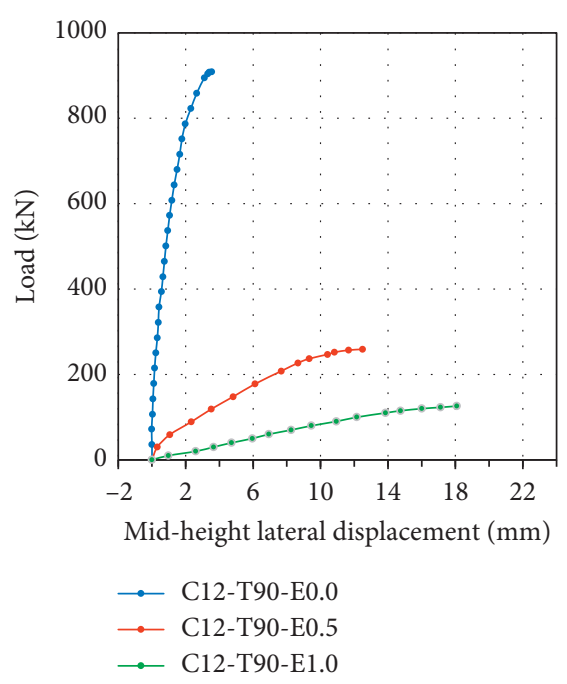

(c)

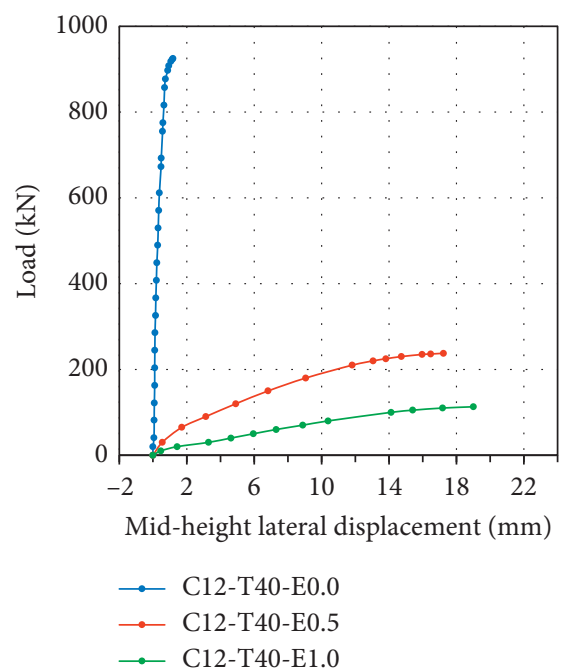

(f)

Figure 7: Load-lateral deflection curves at midheight of the columns.

CFRP-reinforced columns showed lesser slope than steelreinforced columns because the modulus of elasticity of CFRP bars was smaller than that of steel, which affected the column stiffness.

When the longitudinal reinforcement ratio of CFRPreinforced columns was increased from $1.4 \%$ to $3.6 \%$, the slope of the load-deflection curves was increased (Figure 7) for the three cases of eccentricity. The concentric loading column with different tie spacings (e.g., 140, 90, and $40 \mathrm{~mm}$ ) demonstrated different slopes of load-deflection curves. Since concentric columns are deflected in a weaker direction which is not expected, the relation between their deflection curves is not more reliable to be compared, while the direction of lateral deflection for the eccentric column was known. For the columns with $e=0.5 h$, specimen $\mathrm{C} 12$ T40-E0.5 exhibited lesser slope, and the slopes of C12T140-E0.5 and C12-T90-E0.5 were approximately equal. The same phenomenon was observed for columns with $e=1.0 h$.
3.4. Effect of the Parameters. This section discusses the effect of test parameters, including type of reinforcement, eccentricity, longitudinal reinforcement ratio, and tie spacing on the maximum carrying capacity of the columns (Table 3).

3.4.1. Type of Reinforcement. The CFRP-reinforced columns exhibited lower strength than the steel-reinforced columns with a small difference for concentric-loaded columns and columns with $e=1.0 \mathrm{~h}$. However, the difference was high for columns with $e=0.5 \mathrm{~h}$. The ratio of maximum load of CFRPreinforced columns to that of those reinforced with steel bars was $99.2 \%, 88.2 \%$, and $96.9 \%$ for eccentricity levels equal to $0.0,0.5 \mathrm{~h}$, and $1.0 \mathrm{~h}$, respectively.

3.4.2. Eccentricity to Depth Ratio $(e / h)$. The test results shown in Table 3 and load deflection curves in Figure 7 show that eccentricity plays a remarkable role on the axial capacity 
and stiffness of the column specimens. For the steel-reinforced column, the maximum load of S12-T90-E0.5 and S12T90-E1.0 was $32.4 \%$ and $14.2 \%$ of that of the column S12T90-E0.0, respectively. Thus, compared with the concentrically loaded specimen, the specimens with eccentricity equal to $0.5 \mathrm{~h}$ and $1.0 \mathrm{~h}$ showed decreased column axial capacity by $67.6 \%$ and $85.8 \%$, respectively. The maximum load of columns with 140 and $90 \mathrm{~mm}$ tie spacing and different longitudinal reinforcement ratios decreased by an average of $70.3 \%$ and $85.9 \%$ for specimens with $e=0.5$ and $1.0 h$ compared with the concentric-loaded specimens, respectively. But, specimens with tie spacing equal to $40 \mathrm{~mm}$ showed a slightly larger effect of eccentricity. The maximum load was decreased to $74.3 \%$ and $87.8 \%$ for $e=0.5$ and $1.0 \mathrm{~h}$, respectively.

3.4.3. Longitudinal Reinforcement Ratio. For concentrically loaded columns, raising the longitudinal reinforcement ratio from $1.4 \%$ to $2.0 \%$ and $3.6 \%$ increased carrying capacity by $6 \%$ and $12 \%$, respectively. For columns with $e=0.5 h$, axial capacity was unremarkably increased by $2 \%$ when longitudinal reinforcement ratio was changed from $1.4 \%$ to $2.0 \%$. Axial capacity increased by $13 \%$ at a longitudinal reinforcement ratio of $3.6 \%$. For column specimens with $e=1.0 h$, a $6 \%$ increase and a $15 \%$ increase in axial capacity of the column were marked for longitudinal reinforcement ratios equal to $2.0 \%$ and $3.6 \%$, respectively. This result showed that with increasing eccentricity, the influence of increasing longitudinal reinforcement to $3.6 \%$ was evident.

3.4.4. Tie Spacing. This section considers the effect of CFRP tie spacing (transverse reinforcement) on the maximum carrying capacity of the columns. The test results for concentric columns in Table 3 showed that the axial capacity of the column slightly increased by $1.11 \%$ and $2.89 \%$ when the tie spacing decreased from $140 \mathrm{~mm}$ to 90 and $40 \mathrm{~mm}$, respectively. For the column with $e=0.5 \mathrm{~h}$, decreasing tie spacing from $140 \mathrm{~mm}$ to 90 and $40 \mathrm{~mm}$ reduced axial capacity by $0.76 \%$ and $9.96 \%$, respectively. The axial capacity for the column with $e=1.0 h$ was reduced by $2.33 \%$ and $12.40 \%$ when tie spacing decreased from $140 \mathrm{~mm}$ to 90 and $40 \mathrm{~mm}$, respectively. For columns with $e=0.5$ and $1.0 \mathrm{~h}$, unremarkable change in axial capacity was observed when tie spacing decreased from $140 \mathrm{~mm}$ to $90 \mathrm{~mm}$. Axial capacity evidently changed when tie spacing decreased from $140 \mathrm{~mm}$ to $40 \mathrm{~mm}$. Decreasing tie spacing to $40 \mathrm{~mm}$ (close distance) created a separated plane between the shell concrete cover and the concrete core, which caused the concrete cover to spall off or break and leads to failure $[18,26]$.

\section{Theoretical Analysis}

4.1. Theoretical Capacity Calculation. In this section, theoretical axial capacity and bending moment were calculated for columns reinforced with FRP (CFRP and GFRP) bars at different eccentricity levels. The calculations were based on strain compatibility and equilibrium of internal forces for the column. The calculation was applied on 61 FRP bar-reinforced column specimens from the present study and previous works [18-21, 27-29]. Three different calculation methods were used to determine the axial load capacity and bending moment. In the first calculation method, the contribution of the FRP bar in resisting compression stress was ignored, as recommended by ACI 440.1R-15 and CSA/CAN S806-12 [18]. In the second method [18], the contribution of the FRP bars in compression was included. The FRP bar strain for concentricloaded columns was approximately equal to the ultimate concrete strain (0.003). FRP bars are assumed to exhibit the same modulus of elasticity in compression and tension [30].

In the third calculation method, many trials were applied to determine the contribution of FRP in resisting compression stress. Different ratios of compressive modulus of elasticity ranging between $70 \%$ and $90 \%$ of their tensile modulus of elasticity were used. The results of the proposed theoretical model were compared with the experimental results. The best ratios were $80 \%$ and $75 \%$ for CFRP and GFRP bars, respectively.

The analytical nominal axial and bending moment capacity $\left(P_{\mathrm{n}}\right.$ and $M_{\mathrm{n}}$, respectively) were calculated on the basis of strain compatibility and internal force equilibrium on the cross-sectional area of the column, as shown in Figure 8.

Equivalent rectangular stress block, as defined by ACI 318-14 [24], was used to compute the contribution of concrete in the compression zone. A linear stress-strain relationship for FRP bars was used to calculate the force resisted by compression and tension in the FRP bars. Each compression stress, strain, and force in this analysis was considered positive, and the tensile stress, strain, and force were considered negative.

For the first calculation method, the nominal axial capacity of the concentric-loaded column can be calculated using the following equation:

$$
P_{\mathrm{n}}=0.85 f_{\mathrm{c}}^{\prime}\left(A_{\mathrm{g}}-A_{\mathrm{f}}\right)
$$

where $P_{\mathrm{n}}$ is the nominal axial capacity of the column, $f_{\mathrm{c}}^{\prime}$ is the concrete cylinder compressive strength at 28 days, $A_{\mathrm{g}}$ is the gross area of the column cross section, and $A_{\mathrm{f}}$ is the total cross-sectional area of FRP bars.

For the second and third calculation method where contribution of FRP bars in compression was considered, the nominal axial capacity of the concentric column was computed by the following equation:

$$
P_{\mathrm{n}}=\gamma f_{\mathrm{c}}^{\prime}\left(A_{\mathrm{g}}-A_{\mathrm{f}}\right)+0.003\left(k E_{\mathrm{f}} A_{\mathrm{f}}\right),
$$

where $E_{\mathrm{f}}$ is the tensile modulus of elasticity of the FRP bar, $k=1$ is used for the second calculation method [18], and $k=0.80$ and 0.75 is used for CFRP and GFRP bars in the proposed third calculation method, respectively.

The following equations were adopted to determine $P_{\mathrm{n}}$ and $M_{\mathrm{n}}$ for the rectangular column under eccentric loading (Figure 8(a)): 


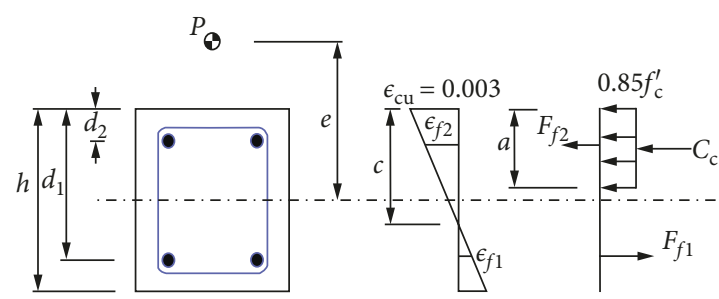

(a)

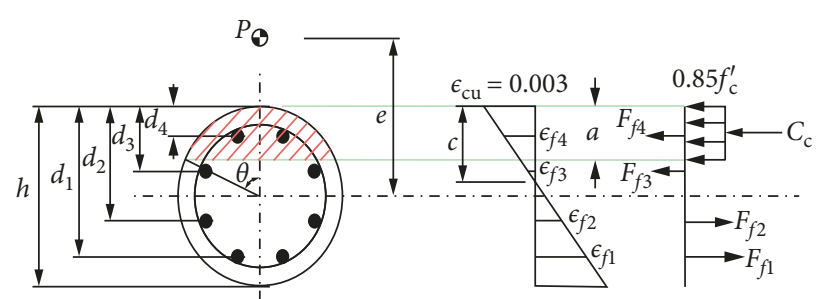

(b)

FIgURE 8: Strain compatibility and force equilibrium of cross section of FRP-reinforced concrete column. (a) Rectangular column. (b) Circular column.

$$
\begin{aligned}
& \epsilon_{f i}=0.003\left(\frac{c-d_{i}}{c}\right), \\
& f_{f i}=\epsilon_{f i} \cdot E_{\mathrm{f}}, \\
& F_{f i}=A_{f i} \cdot f_{f i},
\end{aligned}
$$

where $c$ is the neutral axis depth, $d_{i}$ is the the distance between the extreme compression fibre and $i$ th bar centre, $\epsilon_{f i}$ and $f_{f i}$ are the strain and stress in $i$ th FRP bars, and $F_{f i}$ is the the force in $i$ th FRP bars.

$$
\begin{aligned}
a & =\beta_{1} c, \\
C_{c} & =\gamma f_{c}^{\prime} \cdot a b,
\end{aligned}
$$

where $a$ is the height of the equivalent rectangular block stress of concrete, $\beta_{1}$ is the factor defined by ACI 318-14 used for calculating $a$ with respect to $c, \gamma=0.85$ for ACI440.1R-15 and Hadi et al. [18] and $\gamma=0.8$ for the proposed method, and $C_{\mathrm{c}}$ is the internal compression force developed in concrete.

$$
\begin{aligned}
P_{\mathrm{n}} & =C_{\mathrm{c}}+\sum F_{f i}, \\
M_{\mathrm{n}} & =C_{\mathrm{c}}\left(\frac{h}{2}-\frac{a}{2}\right)+\sum\left(F_{f i}\left(\frac{h}{2}-d_{i}\right)\right),
\end{aligned}
$$

where $P_{\mathrm{n}}$ and $M_{\mathrm{n}}$ are the nominal axial load and bending moment resisted by the column cross section, respectively.

The same strain compatibility and force equilibrium equations mentioned above are used for circular columns (Figure 8(b)) considering the shape change of cross section from rectangular to circular. The following equations were used to calculate the compressive force resisted by the concrete and its moment about centroid:

$$
\begin{aligned}
\theta & =\cos ^{-1}\left(\frac{(h / 2)-a}{h / 2}\right), \\
C_{\mathrm{c}} & =0.85 f_{\mathrm{c}}^{\prime} \cdot h^{2}\left(\frac{\theta-\sin \theta \cos \theta}{4}\right), \\
y & =\left(\frac{h}{3}\right)\left(\frac{\sin ^{3} \theta}{\theta-\sin \theta \cdot \cos \theta}\right),
\end{aligned}
$$

where $y$ is the distance from the centroid of the section to the centroid of the concrete compressive stress block.
4.2. Difference among Theoretical Models. To verify the three methods ACI 440.1R-15 [1], Hadi et al. [18], and Proposal, the ratio of experimental to theoretical axial load capacity $\left(P_{\text {Exp. }} / P_{\text {Theor. }}\right)$ was calculated for the 61 rectangular and circular concrete columns reinforced with GFRP or CFRP as rebars from present works and available in the literature. The mean, standard deviation (SD), and coefficient of variation (COV) were computed and are listed in Table 4.

The better mean value (1.05) for the three methods was obtained from the method proposed. The proposed method also showed the least COV value $(9.88 \%)$. Conservative values for mean (1.08) and COV (11.62\%) were observed in the ACI 440.1R-15 method. The conservative values of ACI $440.1 \mathrm{R}-15$ were reflected in the minimum and maximum values of $P_{\text {Exp. }} / P_{\text {Theor. }}$ which are equal to 0.87 and 1.49 , respectively, and the minimum value of the number of specimens that got $P_{\text {Exp. }} / P_{\text {Theor. }}$ less than 1.0 is equal to 16 .

Figure 9 shows the experimental versus theoretical values of axial capacity for the three calculation methods. These three graphs show that most of the data were distributed diagonally (the diagonal represent the best agreement between experimental and theoretical equations results). The ACI-440.1R-15 data were scattered, most of which occurred above the diagonal area. Hadi et al.'s graph shows that most of the data were below the diagonal, whereas the proposed graph showed improved data distribution and less data scattered around the diagonal area.

4.3. Effect of the Parameters. The ratios of $P_{\text {Exp. }} / P_{\text {Theor. }}$ for the three methods were plotted versus the eccentricity to depth ratio $(e / h)$, concrete compressive strength $\left(f_{c}^{\prime}\right)$, and longitudinal reinforcement ratio $\left(\rho_{\mathrm{f}}\right)$ for the 61 FRP concrete columns, to assess the influence of the main parameters on the theoretical models used (Figure 10). A decreasing trend in $P_{\text {Exp. }} / P_{\text {Theor. }}$ occurred in the ACI $440.1 \mathrm{R}-15$ method when $e / h$ was increased up to 1.0. However, no remarkable changes were observed for the two other methods. As $f_{c}^{\prime}$ was increased to approximately $45 \mathrm{MPa}$, an evident decrease in the factor of safety (ratio of $P_{\text {Exp. }} / P_{\text {Theor. }}$ ) was observed. This observation was true for the three methods. It is seen that there is lack of experimental data in high-strength concrete, except a few data at 70.2 $\mathrm{MPa}$. Therefore, further research studies for $f_{c}^{\prime}$ greater than $45 \mathrm{MPa}$ are needed. An increase in factor of safety was observed in the three methods for $\rho_{\mathrm{f}}$ up to $2.2 \%$. This increase was remarkable in ACI-440.1R-15. For 
TABLe 4: Comparison of $P_{\text {Exp. }} / P_{\text {Theo }}$ by the three calculation methods for 61 concrete columns reinforced with FRP bars.

\begin{tabular}{lccc}
\hline Calculation method & Method 1: ACI 440.1R-15 [1] & Method 2: Hadi et al. [18] & Method 3: proposal \\
\hline Equation used & $(1)$ and (3) to (6) & (2) and (3) to (6) & $(2)$ and (3) to (6) \\
Mean & 1.08 & 0.97 & 1.05 \\
SD & 0.13 & 0.10 & 0.10 \\
COV (\%) & 11.62 & 9.95 & 9.88 \\
Range: & 0.87 & & 0.79 \\
$\quad$ Min. & 1.49 & 1.18 & 0.85 \\
$\quad$ Max. & 16 & 35 & 1.26 \\
Number $<1.0^{*}$ & & 24 \\
\hline
\end{tabular}

*Number of specimens (out of 61) having $P_{\text {Exp. }} / P_{\text {Theo }}$ less than one.

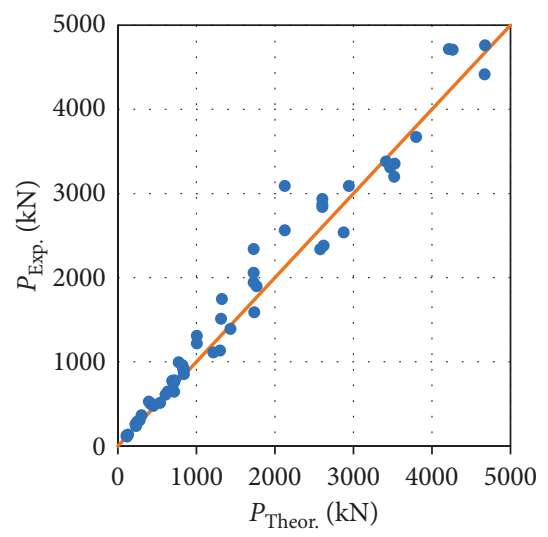

(a)

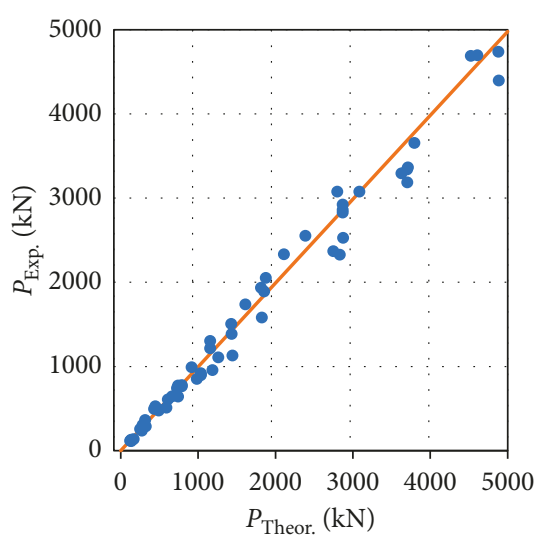

(b)

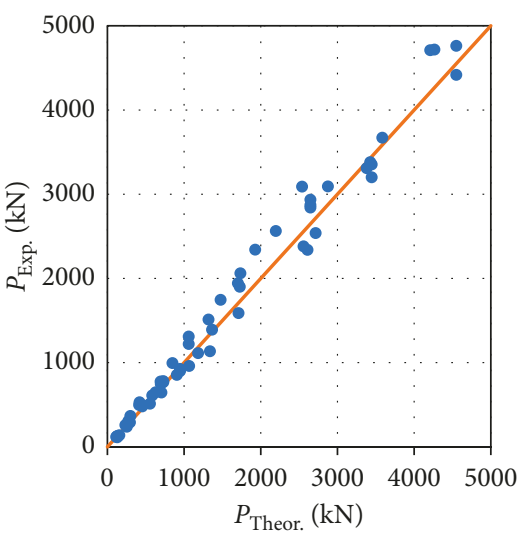

(c)

Figure 9: Experimental versus theoretical axial load capacity. (a) ACI 440.1R-15. (b) Hadi et al. [18]. (c) Proposal.
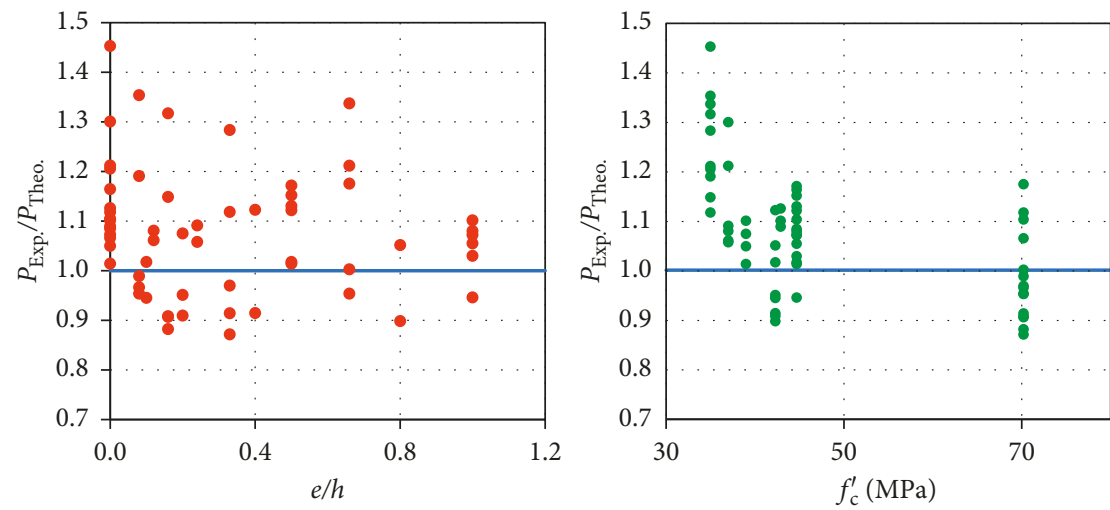

(a)

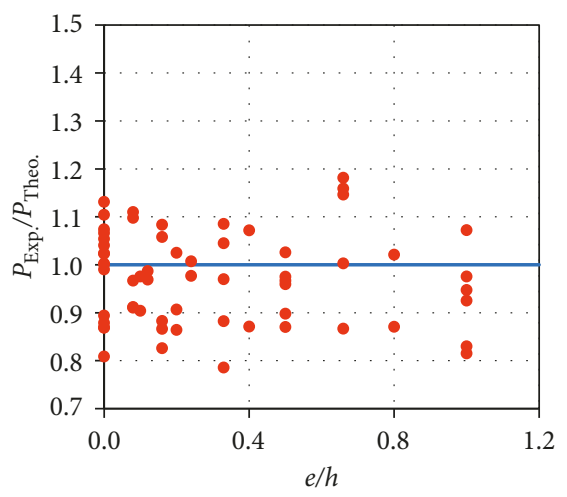

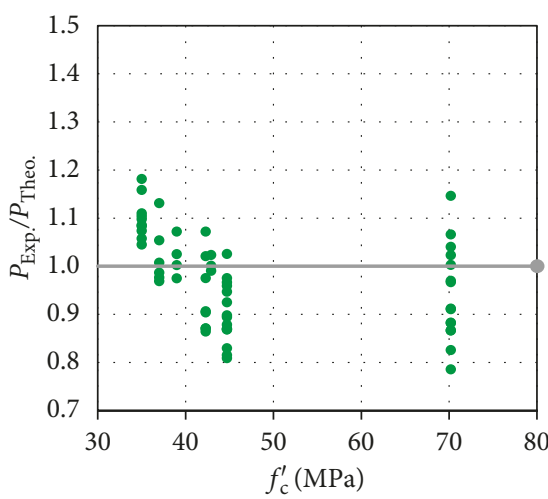

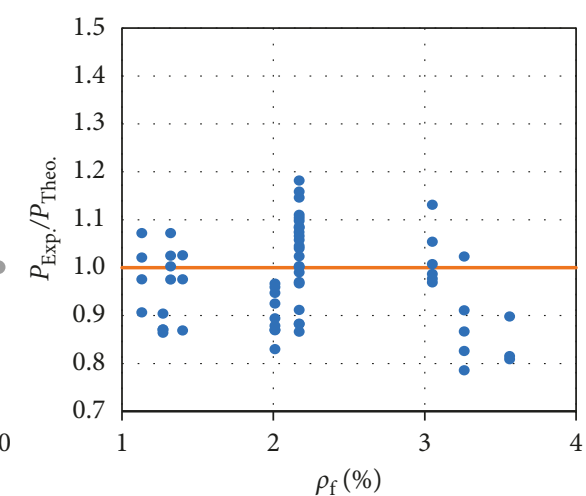

(b)

Figure 10: Continued. 

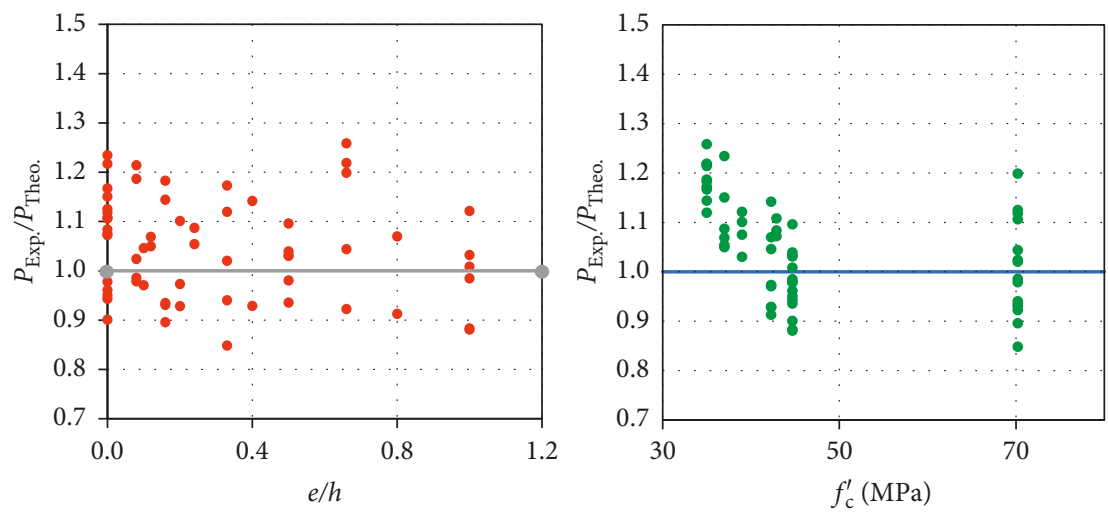

(c)

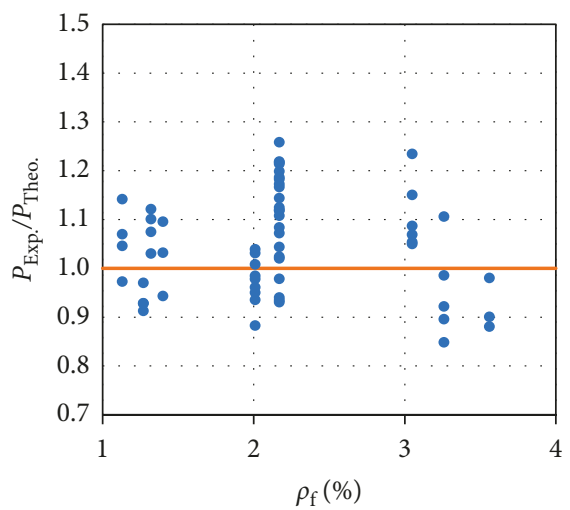

Figure 10: Effect of $e / h, f_{\mathrm{c}}^{\prime}$, and $\rho_{\mathrm{f}}$ on the test results. (a) ACI 440.1R-15. (b) Hadi et al. [18]. (c) Proposal.

$\rho_{\mathrm{f}}$ from $2.2 \%$ to $3.6 \%$, the factor of safety for the three methods was decreased. This decrease was less evident in the proposed method.

\section{Conclusions}

The following conclusions and recommendations could be drawn on the basis of the experimental and the theoretical analysis results:

(1) The CFRP concrete columns behaved similarly to their conventional steel-reinforced concrete column counterparts with insignificant reduction in axial and flexural capacity.

(2) The percentage of eccentricity considerably affected the behaviour and mode of failure of the CFRP RC columns.

(3) Decreasing tie spacing from $140 \mathrm{~mm}$ to $40 \mathrm{~mm}$ unremarkably affected the axial capacity for the concentric-loaded columns, as shown by the $2.9 \%$ increase, while decreasing tie spacing for columns subjected to eccentric load reduced axial capacity, reaching $12.4 \%$ for a column with $e / h=1.0$.

(4) All eccentric concrete columns reinforced with CFRP bars failed by concrete crushing in compression side, and the maximum tensile strain in the longitudinal bars, which was recorded in columns with $1.4 \%$ reinforcement ratio, did not exceed $34 \%$ of the ultimate tensile strain of the bar.

(5) A theoretical approach was proposed to predict the axial and moment carrying capacity of the concrete columns reinforced with FRP bars. The axial ratios of $P_{\text {Exp. }} / P_{\text {Theor. }}$ computed by this approach and by two other methods for 61 specimens showed that the proposed model exhibited the better mean value of 1.05 and the least COV of $9.88 \%$.

(6) A theoretical analysis based on ACI 440.1R-15 leads to conservative prediction of axial carrying capacity ratios $\left(P_{\text {Exp. }} / P_{\text {Theor. }}\right)$ for concrete columns reinforced with FRP bars.
(7) Experimental data in high-strength concrete, except for few findings at $70.2 \mathrm{MPa}$, are lacking. Therefore, further research for $f_{\mathrm{c}}^{\prime}$ greater than $45 \mathrm{MPa}$ is required.

\section{Data Availability}

The data used to support the findings of this study are included within the article.

\section{Conflicts of Interest}

The authors declare that there are no conflicts of interest regarding the publication of this paper.

\section{References}

[1] American Concrete Institute, Guide for the Design and Construction of Structural Concrete Reinforced with Fiber Reinforced Polymer (FRP) Bars (ACI 440.1 R-15), American Concrete Institute, Farmington Hills, MI, USA, 2015.

[2] S. H. Alsayed, Y. A. Al-Salloum, T. H. Almusallam, and M. A. Amjad, Concrete Columns Reinforced by Glass Fiber Reinforced Polymer Rods, Vol. 188, American Concrete Institute, Farmington Hills, MI, USA, 1999.

[3] A. D. Luca, F. Matta, and A. Nanni, "Behavior of full-scale glass fiber-reinforced polymer reinforced concrete columns under axial load," ACI Structural Journal, vol. 107, no. 5, p. $589,2010$.

[4] E. M. Lotfy, "Behavior of reinforced concrete short columns with Fiber Reinforced polymers bars," International Journal of Civil and Structural Engineering, vol. 1, no. 3, p. 545, 2010.

[5] H. Tobbi, A. S. Farghaly, and B. Benmokrane, "Concrete columns reinforced longitudinally and transversally with glass fiber-reinforced polymer bars," ACI Structural Journal, vol. 109, no. 4, 2012.

[6] M. Z. Afifi, H. M. Mohamed, and B. Benmokrane, "Axial capacity of circular concrete columns reinforced with GFRP bars and spirals," Journal of Composites for Construction, vol. 18, no. 1, article 04013017, 2014.

[7] W. Prachasaree, A. Sangkaew, S. Limkatanyu, and H. V.S. GangaRao, "Parametric study on dynamic response of fiber reinforced polymer composite bridges," International 
Journal of Polymer Science, vol. 2015, Article ID 565301, 13 pages, 2015.

[8] H. Karim, B. Noel-Gough, M. N. Sheikh, and M. N. Hadi, Strength and Ductility Behavior of Circular Concrete Columns Reinforced with GFRP Bars and Helices, Southeast University, Nanjing, China, 2015.

[9] H. Karim, M. N. Sheikh, and M. N. S. Hadi, "Axial load-axial deformation behaviour of circular concrete columns reinforced with GFRP bars and helices," Construction and Building Materials, vol. 112, pp. 1147-1157, 2016.

[10] M. Z. Afifi, H. M. Mohamed, and B. Benmokrane, "Strength and axial behavior of circular concrete columns reinforced with CFRP bars and spirals," Journal of Composites for Construction, vol. 18, no. 2, article 04013035, 2013.

[11] H. M. Mohamed, M. Z. Afifi, and B. Benmokrane, "Performance evaluation of concrete columns reinforced longitudinally with FRP bars and confined with FRP hoops and spirals under axial load," Journal of Bridge Engineering, vol. 19, no. 7, article 04014020, 2014.

[12] H. Tobbi, A. S. Farghaly, and B. Benmokrane, "Behavior of concentrically loaded fiber-reinforced polymer reinforced concrete columns with varying reinforcement types and ratios," ACI Structural Journal, vol. 111, no. 2, 2014.

[13] C. C. Choo, I. E. Harik, and H. Gesund, "Strength of rectangular concrete columns reinforced with fiber-reinforced polymer bars," ACI Structural Journal, vol. 103, no. 3, p. 452, 2006.

[14] A. Deiveegan and G. Kumaran, "Experimental and reliability studies on the behaviour of concrete columns reinforced internally with glass fibre reinforced polymer reinforcements," Journal of Structural Engineering, vol. 38, no. 5, pp. 457-475, 2011.

[15] C. C. Choo, I. E. Harik, and H. Gesund, "Minimum reinforcement ratio for fiber-reinforced polymer reinforced concrete rectangular columns," ACI Structural Journal, vol. 103 , no. 3, p. 460, 2006.

[16] M. Issa, I. Metwally, and S. Elzeiny, "Structural performance of eccentrically loaded GFRP reinforced concrete columns," International Journal of Civil and Structural Engineering, vol. 2, no. 1, p. 395, 2011.

[17] H. J. Zadeh and A. Nanni, "Design of RC columns using glass FRP reinforcement," Journal of Composites for Construction, vol. 17, no. 3, pp. 294-304, 2013.

[18] M. N. Hadi, H. Karim, and M. N. Sheikh, "Experimental investigations on circular concrete columns reinforced with GFRP bars and helices under different loading conditions," Journal of Composites for Construction, vol. 20, no. 4, article 04016009, 2016

[19] A. Hadhood, H. M. Mohamed, and B. Benmokrane, "Axial load-moment interaction diagram of circular concrete columns reinforced with CFRP bars and spirals: experimental and theoretical investigations," Journal of Composites for Construction, vol. 21, no. 2, article 04016092, 2017.

[20] A. Hadhood, H. M. Mohamed, and B. Benmokrane, "Strength of circular HSC columns reinforced internally with carbonfiber-reinforced polymer bars under axial and eccentric loads," Construction and Building Materials, vol. 141, pp. 366-378, 2017.

[21] M. Guérin, H. M. Mohamed, B. Benmokrane, A. Nanni, and C. K. Shield, "Eccentric behavior of full-scale reinforced concrete columns with glass fiber-reinforced polymer bars and ties," ACI Structural Journal, vol. 115, no. 2, 2018

[22] A. Raza, Q. U. Z. Khan, and A. Ahmad, "Numerical investigation of load-carrying capacity of GFRP-reinforced rectangular concrete members using CDP model in ABAQUS,” Advances in Civil Engineering, vol. 2019, Article ID 1745341, 21 pages, 2019.

[23] N. Elmessalami, A. El Refai, and F. Abed, "Fiber-reinforced polymers bars for compression reinforcement: a promising alternative to steel bars," Construction and Building Materials, vol. 209, pp. 725-737, 2019.

[24] American Concrete Institute, Building Code Requirements for Structural Concrete (ACI 318-14): Commentary on Building Code Requirements for Structural Concrete (ACI 318R-14): An ACI Report, American Concrete Institute (ACI), Farmington Hills, MI, USA, 2014.

[25] ASTM, Standard Test Method for Compressive Strength of Cylindrical Concrete Specimens, ASTM International, West Conshohocken, PA, USA, 2001.

[26] S. R. Razvi and M. Saatcioglu, "Strength and deformability of confined high-strength concrete columns," Structural Journal, vol. 91, no. 6, pp. 678-687, 1994.

[27] A. Hadhood, H. M. Mohamed, F. Ghrib, and B. Benmokrane, "Efficiency of glass-fiber reinforced-polymer (GFRP) discrete hoops and bars in concrete columns under combined axial and flexural loads," Composites Part B: Engineering, vol. 114, pp. 223-236, 2017.

[28] A. Hadhood, H. M. Mohamed, and B. Benmokrane, "Experimental study of circular high-strength concrete columns reinforced with GFRP bars and spirals under concentric and eccentric loading," Journal of Composites for Construction, vol. 21, no. 2, article 04016078, 2017.

[29] W. Xue, F. Peng, and Z. Fang, "Behavior and design of slender rectangular concrete columns longitudinally reinforced with fiber-reinforced polymer bars," ACI Structural Journal, vol. 115, no. 2, pp. 311-322, 2018.

[30] D. H. Deitz, I. E. Harik, and H. Gesund, "Physical properties of glass fiber reinforced polymer rebars in compression," Journal of Composites for Construction, vol. 7, no. 4, pp. 363-366, 2003. 


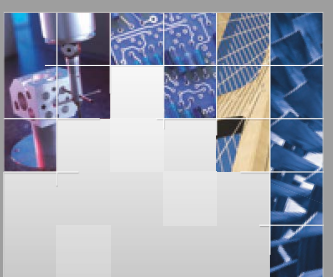

\section{Enfincering}
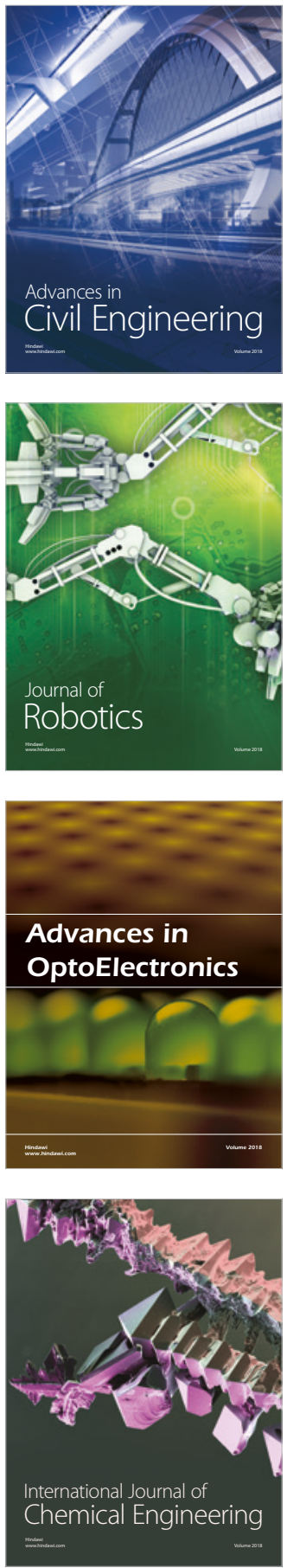

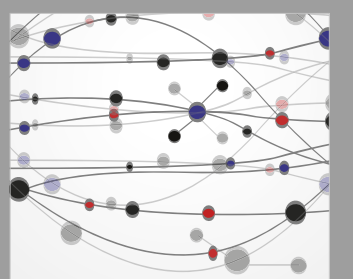

\section{Rotating \\ Machinery}

The Scientific World Journal

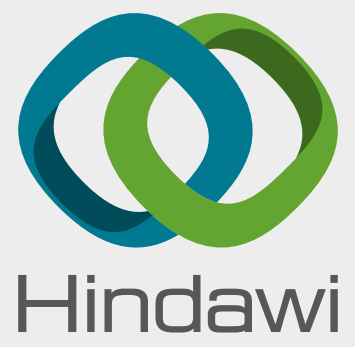

Submit your manuscripts at

www.hindawi.com
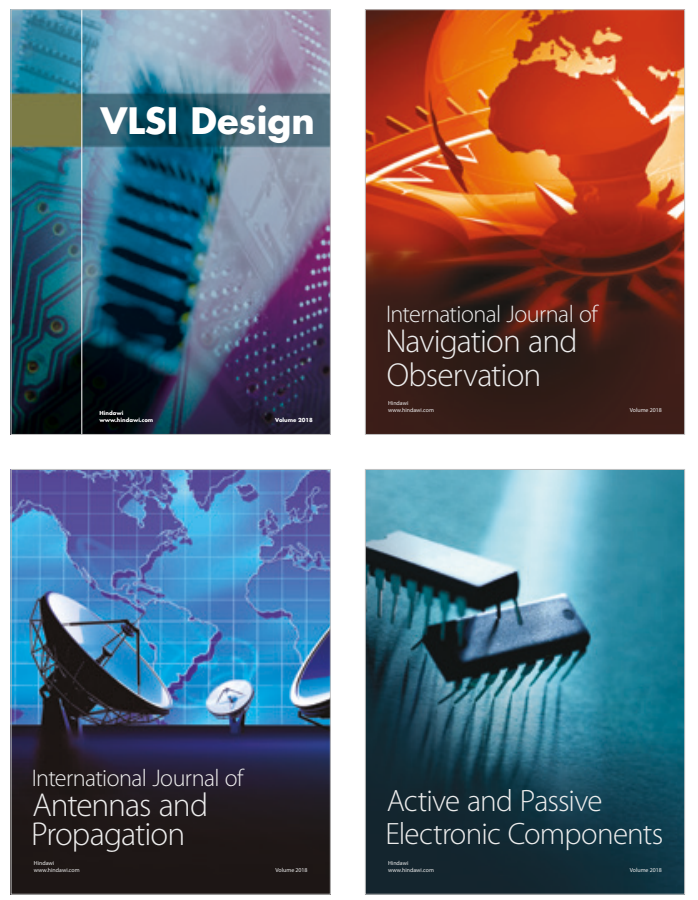
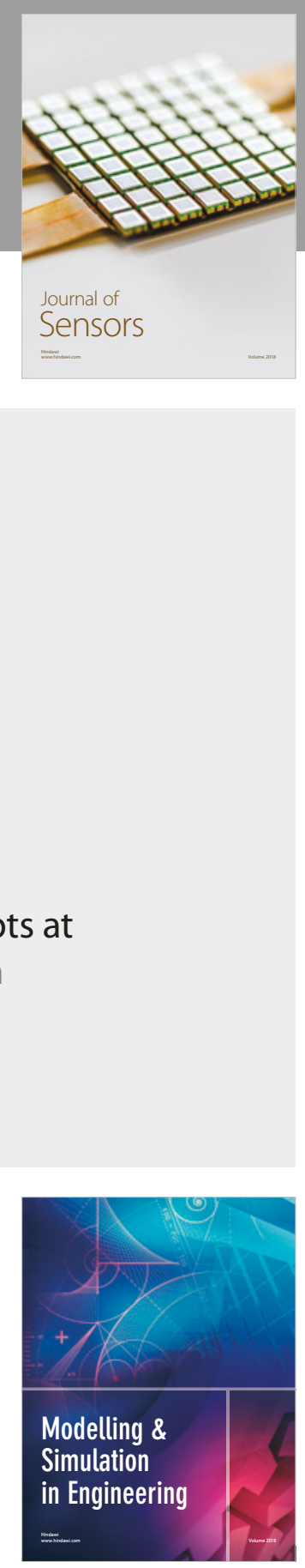

\section{Advances \\ Multimedia}
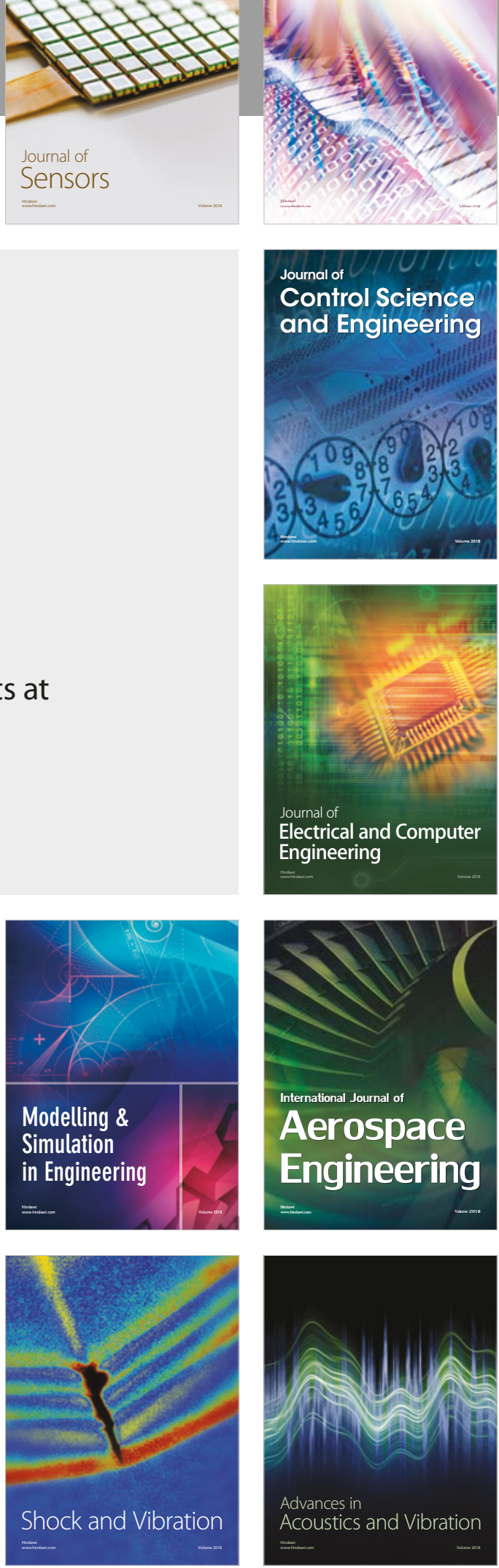